\title{
Pemanfaatan Sumber Belajar Untuk Meningkatkan Literasi Sains Sekolah Dasar (Studi Kasus di Kecamatan Tegalrejo Yogyakarta)
}

\author{
Santy Dinar Permata \\ Pendidikan Guru Sekolah Dasar, STKIP Modern Ngawi, santydinar@stkipmodernngawi.ac.id \\ Tri Wardati Khusniyah \\ Pendidikan Guru Sekolah Dasar, STKIP Modern Ngawi, khusniyah.tw@stkipmodernngawi.ac.id
}

\begin{abstract}
Abstrak
Budaya literasi merupakan salah satu kompetensi yang perlu dimiliki oleh masyarakat saat ini guna menghadapi tantangan kemajuan teknologi industri yang pesat. Pemerintah Indonesia menciptakan program Gerakan Literasi Sekolah pada semua jenjang pendidikan tak terkecuali sekolah dasar. Dalam pelaksanaan GLS memerlukan sumber belajar yang tepat guna mengoptimalkan peningkatan kemampuan literasi siswa. Penelitian ini bertujuan mengetahui sumber belajar yang digunakan pada sekolah dasar di Kecamatan Tegalrejo, Yogyakarta untuk meningkatkan kemampuan literasi sains. Penelitian ini menggunakan jenis penelitian kualitatif deskriptif dengan pendekatan studi kasus. Teknik pengumpulan data melalui observasi dan wawancara yang melibatkan guru dan siswa di kelas V SD Kecamatan Tegalrejo Yogyakarta. Data dianalisis menggunakan teknik analisis secara interaktif. Hasil penelitian menunjukkan sekolah menggunakan ragam sumber belajar dalam kegiatan GLS yang disesuaikan dengan kebutuhan siswa.
\end{abstract}

Kata Kunci: literasi sains, sumber belajar, studi kasus

\section{PENDAHULUAN}

Masa ini, dunia dihadapkan dengan revolusi industri 4.0 dimana unsur percepatan dan ketersediaan teknologi serta informasi berkembang dengan sangat cepat. Menggemanya revolusi industri 4.0 memberikan peluang kepada setiap negara untuk bersaing menginovasi teknologi-teknologi terbaru guna mempermudah kehidupan masyarakat melalui perdagangan global. Bersamaan dengan hal tersebut, transformasi industri ini juga memberikan tantangan kepada dunia pendidikan khususnya untuk menghasilkan sumber daya manusia yang kompetitif, kreatif dan inovatif terhadap perkembangan zaman. Dengan demikian perubahan teknologi informasi yang pesat dapat terimbangi dengan adanya sumber daya manusia yang cakap dan memadai sehingga dampak buruk adanya disrupsi teknologi informasi dapat terkendali.

UNESCO tahun 2003 pada Deklarasi Praha memperhatikan bahwa era global seperti ini, seseorang dituntut untuk menjadi pribadi yang literat. Seseorang dinyatakan literat apabila dirinya memiliki kompetensi maupun kecakapan hidup dengan didasari pada kesadaran untuk mempelajari beragam hal, mampu mengaplikasikan dalam kehidupan serta mampu berkontribusi untuk kebermanfaatan bersama. Indonesia sebagai negara yang terus mengikuti perkembangan zaman melihat era perubahan teknologi informasi yang pesat ini sebagai suatu peluang untuk menginovasi dan mengkreasikan beragam teknologi guna bersaing di dunia industri global. Kebutuhan untuk beradaptasi dengan kemajuan teknologi informasi menginisiasi Negara Kesatuan Republik Indonesia untuk menyediakan suatu program pendidikan agar masyarakat menjadi pribadi literat melalui Gerakan Literasi Nasional. Program ini dicanangkan sebagai strategi untuk mengintegrasikan masyarakat Indonesia dengan perkembangan zaman serta meningkatkan 
produktivitas masyarakat guna bersaing di pasar global.

\section{Gerakan Literasi Nasional (GLN)} diterapkan dalam tiga ranah yaitu pada lingkungan sekolah, keluarga dan masyarakat. GLN pada tingkat sekolah selanjutnya disebut Gerakan Literasi Sekolah (GLS) dikembangkan berdasarkan Nawacita Presiden Republik Indonesia, Bapak Ir. Joko Widodo untuk membentuk sumber daya manusia yang berkualitas, berkarakter serta berdaya saing global serta diatur dalam Permendikbud No 23 Tahun 2015 tentang Penumbuhan Budi Pekerti.

Sekolah merupakan pihak yang berperan aktif terselenggaranya kegiatan literasi. Dijelaskan oleh Wiedarti dkk. (2016) komponen literasi yang diajarkan di sekolah salah satunya adalah literasi dasar. Dalam literasi dasar termuat literasi sains yang bertujuan untuk memberikan pemahaman maupun kesadaran kepada seseorang tentang lingkungan alam semesta. Perkembangan teknologi informasi yang pesat tak memungkiri akan memberikan dampak negatif kepada lingkungan dikarenakan adanya pemanfaatan sumber daya yang berlebihan dari alam untuk memenuhi bahanbahan penyusun teknologi. Adanya eksploitasi sumber daya alam tanpa diimbangi dengan kesadaran seseorang tentang timbal balik yang mungkin terjadi di lingkungan alam akan menyebabkan kerusakan bagi kehidupan makhluk hidup, tak terkecuali bagi manusia.

Literasi sains sebagaimana disebutkan oleh Programme for International Student Assessment (PISA, 2018) merupakan kemampuan seseorang dalam memahami konsep, fenomena dan proses ilmiah serta mampu menerapkannya pada permasalahan yang terdapat dalam kehidupan sehari-hari. Hal tersebut menjelaskan bahwa melalui pengembangan literasi sains dapat membantu seseorang atau siswa meningkatkan pemahaman dan keterampilan ilmiahnya yang berkaitan dengan pemecahan masalah dan terlibat kepedulian terhadap isu-isu sains di lingkungan sekitar. Melalui literasi sains siswa diharapkan tidak hanya mampu menguasai teori sains saja tetapi juga mampu memprediksi dampakdampak dari perkembangan sains dan teknologi terhadap lingkungan alam.

Pelaksanaan literasi sesuai tata laksana GLS dapat diterapkan dalam kegiatan membaca selama 15 menit sebelum pembelajaran dimulai. Sesuai dengan hasil observasi yang dilakukan peneliti di Kecamatan Tegalrejo Yogyakarta, ditemukan bahwa pelaksanaan GLS sudah terlaksana dengan baik di empat sekolah yaitu SDN Bangunrejo 1, SDN Petinggen, SDN Bener dan SDN Tegalrejo 1. Keempat sekolah tersebut menjelaskan bahwa pelaksanaan GLS sudah berlangsung sejak 2015 atau sejak diedarkannya program tersebut di sekolah.

Fasilitas sarana dan prasarana menjadi hal yang sangat diperlukan untuk memaksimalkan terlaksananya program GLS. Salah satu penunjang GLS adalah sumber belajar yang digunakan untuk mempelajari fenomenafenomena sains. Sumber belajar menurut Samsinar (2019) merupakan segala sesuatu yang digunakan untuk memaksimalkan pelaksanaan belajar. Lebih lanjut dijelaskan bahwa sumber belajar dapat berupa data, metode, media maupun tempat yang mana semuanya berfungsi untuk memudahkan para siswa dalam melaksanan proses belajar. Penggunaan sumber belajar yang tepat pada saat pelaksanaan GLS dapat memotivasi serta meningkatkan kemampuan literasi siswa.

Sekolah dasar di tempat penelitian telah membudayakan kegiatan literasi dalam 5 tahun terakhir ini. Sekolah-sekolah tersebut bahkan memiliki waktu khusus untuk kegiatan literasi yang disesuaikan dengan kebutuhan dalam rangka meningkatkan kemampuan literasi siswanya. Budaya literasi yang sudah berjalan di sekolah-sekolah tersebut selanjutnya menjadi pertanyaan apakah sumber belajar yang digunakan sekolah dasar di Kecamatan 
Tegalrejo Yogyakarta untuk meningkatkan literasi sains siswa guna menunjang pelaksanaan GLS? Berdasarkan uraian tersebut maka penelitian ini bertujuan untuk mengetahui sumber belajar yang digunakan Sekolah Dasar di Kecamatan Tegalrejo Yogyakarta untuk meningkatkan literasi sains kepada siswa guna menunjang kegiatan GLS.

\section{METODE}

Penelitian ini menggunakan jenis penelitian kualitatif deskriptif dengan pendekatan studi kasus (case study) untuk mengetahui sumber belajar yang digunakan dalam meningkatkan literasi sains kepada siswa sekolah dasar di Kecamatan Tegalrejo Yogyakarta. Penelitian ini dilaksanakan pada bulan Januari yang melibatkan empat sekolah dasar di Kecamatan Tegalrejo Yogyakarta pada siswa dan guru kelas V. Sampel penelitian dipilih menggunakan teknik simple random sampling.

Teknik pengumpulan data yang digunakan adalah wawancara dan observasi kepada guru dan siswa sekolah dasar kelas V. Instrumen wawancara dan observasi penelitian merujuk pada kisi-kisi berikut:

Tabel 1. Kisi-kisi Wawancara dan Observasi

\begin{tabular}{|c|c|}
\hline Variabel & Aspek \\
\hline \multirow{2}{*}{$\begin{array}{lll}\text { Kegiatan } & \text { Literasi } & \text { di } \\
\text { Kelas } & & \end{array}$} & Pelaksanaan GLS \\
\hline & $\begin{array}{l}\text { Kesulitan dan kendala } \\
\text { pelaksanaan GLS }\end{array}$ \\
\hline \multirow{2}{*}{$\begin{array}{l}\text { Penggunaan Sumber } \\
\text { Belajar }\end{array}$} & Sarana penunjang GLS \\
\hline & $\begin{array}{l}\text { Kegiatan } \\
\text { GLS }\end{array}$ \\
\hline
\end{tabular}

Data yang terkumpul selanjutnya dianalisis melalui teknik analisis secara interaktif merujuk pada Miles, Huberman dan Saldana (2014) meliputi kegiatan reduksi data, penyajian data dan kesimpulan.

\section{HASIL DAN PEMBAHASAN}

Sesuai dengan Permendikbud No 23 tahun 2015 tentang penumbuhan budi pekerti,
Gerakan literasi menjadi salah satu komponen kemampuan yang perlu ditingkatkan sebagai bentuk pengoptimalan olah pikir masyarakat dalam menghadapi tantangan teknologi industri masa kini. Program tersebut selanjutnya diimplementasikan pada sekolah, masyarakat serta keluarga. Di sekolah, program tersebut dikenal dengan istilah Gerakan Literasi Sekolah (GLS). Setiap jenjang pendidikan dari sekolah dasar hingga menengah atas mulai menerapkan program tersebut tak terkecuali pada sekolah dasar di kecamatan Tegalrejo Yogyakarta. Pelaksanaan GLS dapat maksimal apabila didukung oleh sumber belajar yang memadai dan disesuaikan dengan kebutuhan serta karakteristik siswa. Sebagaimana hal tersebut maka pelaksanaan GLS di empat sekolah dasar di kecamatan Tegalrejo Yogyakarta juga menggunakan sumber belajar untuk mendukung optimalisasi kemampuan literasi siswa.

Berdasarkan hasil observasi yang dilakukan di SDN Bangunrejo 1, SDN Petinggen, SDN Tegalrejo 1 dan SDN Bener Kecamatan Tegalrejo Yogyakarta menunjukkan bahwa keempat sekolah tersebut menggunakan beberapa sumber belajar untuk mendukung peningkatan kemampuan literasi sains siswanya. SDN Bangunrejo 1 menggunakan sumber belajar berupa alat proyektor dan LCD dengan menampilkan cerita yang sama di layar agar dapat dibaca bersama-sama, baik guru dan siswa. Supaya kemampuan literasi sains siswa meningkat, guru mengajak siswa untuk membaca informasi terkait tokoh atau ilmuan dunia yang kemudian dikaitkan dengan ruang lingkup literasi sains seperti lingkungan alam, alam semesta, gaya dan lain sebagainya. Melalui penggunaan sumber belajar berupa alat proyektor dan LCD menurut guru kelas dirasa sangat efektif memfokuskan siswa untuk membaca dikarenakan tampilannya yang menarik (terdapat warna, gambar ataupun video). 
Penggunaan sumber belajar berupa alat proyektor dan LCD yang digunakan oleh SDN Bangunrejo 1 memberikan dampak positif terhadap perkembangan kemampuan literasi sains siswa. Hal tersebut sesuai dengan hasil temuan yang dilakukan De Sousa, Richter, Nel (2017) bahwa dengan penggunaan multimedia pada materi sains dapat meningkatkan kemampuan sains siswa dikarenakan siswa dilibatkan secara langsung baik audio maupun visual sehingga hal tersebut memberikan pembelajaran yang bermakna bagi siswa serta menarik dan juga meningkatkan motivasi mereka untuk terus belajar. Hal yang sama juga terjadi pada siswa kelas V SDN Bangunrejo 1, saat penelitian berlangsung nampak siswa sangat antusias untuk membaca bersama dan juga terfokus untuk melakukan kegiatan tersebut. Saat siswa diminta untuk menjelaskan kembali bacaan yang telah dibaca bersama, mereka dapat menyebutkan kembali dengan baik menggunakan bahasanya masing-masing. Hasil pengamatan tersebut sejalan dengan Idami (2018) yang menjelaskan bahwa penggunaan LCD di kelas menciptakan suasana yang kondusif sehingga siswa lebih terfokus dan termotivasi untuk belajar.

Lain halnya dengan SDN Bangunrejo 1, di SDN Petinggen, SDN Tegalrejo 1 Kecamatan Tegalrejo Yogyakarta lebih memilih menggunakan buku cerita sebagai sumber belajar siswa dalam melaksanakan GLS. Berdasarkan wawancara, baik guru dan siswa menyebutkan bahwa lebih senang membaca di buku dan lebih mudah membawa, sehingga apabila bacaan yang dibaca saat kegiatan GLS belum selesai dapat mereka lanjutkan sendiri di waktu lain. Kedua sekolah ini mengawali kegiatan GLS dengan literasi agama seperti membaca Al-Qur'an (bagi yang beragama Islam), beribadah pagi (bagi yang beragama Non-Muslim) atau melaksanakan sholat dhuha berjamaah, setelah itu dilanjutkan dengan kegiatan membaca di kelas selama 15-20 menit.
Jenis bacaan yang dibaca siswa dan guru bebas, siswa dapat menentukan sendiri bacaannya. Di akhir kegiatan beberapa siswa akan diminta untuk menceritakan kembali hasil bacaannya dan dituliskan dalam buku catatan khusus untuk kegiatan literasi.

Sumber belajar buku merupakan salah satu sumber belajar yang dapat diaplikasikan untuk meningkatkan kemampuan literasi sains siswa. Sebagaimana disampaikan Kim (2020) bahwa kegiatan membaca dan menulis menggunakan buku dapat diintegrasikan dalam upaya peningkatan kemampuan literasi sains dikarenakan saat membaca buku siswa dihadapkan secara langsung oleh informasi yang mereka dapatkan dalam buku sehingga informasi tersebut secara langsung diproses dan diterima oleh otak. Buku pada umumnya dibaca mandiri oleh seseorang sehingga keterikatan emosional dan pemahaman mereka menjadi lebih berarti dalam aspek kognitif maupun afektif. Pada waktu penelitian ditemui siswa yang melanjutkan bacaannya setelah kegiatan GLS di luar jam pembelajaran sehingga budaya membaca telah terbentuk di sekolah-sekolah tersebut. Siswa juga menyebutkan bahwa mereka sekarang senang membaca buku saat istirahat atau waktu luang lainnya.

Siswa kelas V di SDN Petinggen dan SDN Tegalrejo 1 selesai melaksanakan kegiatan literasi akan menulis di buku catatan khusus terkait buku bacaan yang telah mereka baca yang berisi judul buku, amanat serta halaman buku dimana mereka mengakhiri bacaannya. Sesuai dengan Tompkins (2017) hal tersebut sangat perlu untuk dilakukan untuk menganalisis kemampuan literasi siswa sehingga guru dapat membantu meningkatkan kemampuan literasi siswanya sesuai dengan catatan yang ada di buku catatan GLS. Melalui buku catatan GLS tersebut, guru mampu menganalisis kegiatan literasi yang dilakukan serta membuat rencana perbaikan atas kegiatan literasi selanjutnya. 
Kesenangan siswa dengan membaca memberikan dampak yang lebih. Berdasarkan hasil wawancara yang dilakukan kepada siswa, ia menyebutkan sudah memberanikan diri untuk menuliskan sendiri cerita yang dimiliki dengan belajar dari buku-buku bacaan mereka. Bahkan salah satu siswa menyebutkan telah membuat sebuah buku bacaan ciptaan ia sendiri dan sudah dilombakan ke berbagai perlombaan karya tulis siswa. Hal tersebut menandakan bahwa kegiatan membaca dan menulis akan saling berkaitan, sebagaimana disebutkan oleh Alves, Limpo dan Joshi (2020) bahwa kegiatan membaca dan menulis ibarat seperti bayi kembar siam, sangat berkaitan. Keduanya membantu mengembangkan kemampuan kognitif seseorang. Melalui membaca seseorang akan memiliki banyak pengetahuan dan menambah wawasan. Berawal dari itulah seseorang akan menuangkan atau menyajikan kembali pengetahuan yang sudah didapat dalam bentuk bahasa tulis. Sehingga sangatlah memungkinkan bagi siswa yang sudah terbiasa membaca akan mulai untuk menghasilkan karya dalam bahasa tulis.

Upaya peningkatan kemampuan literasi sains yang dilakukan selanjutnya oleh sekolah penelitian adalah melalui teknik praktik langsung. Lindsay (2011) menjelaskan bahwa literasi sains tercakup dalam tiga ranah yaitu kognitif, afektif dan psikomotor seseorang. Pernyataan tersebut mengartikan bahwa literasi tidak sekedar menambah pengetahuan teoritis seseorang saja tetapi tercakup keseluruhan hingga dalam bentuk tindakan. Literasi sains disebutkan Fananta dkk (2017) tidak hanya membutuhkan pengetahuan saja, tetapi juga mampu membuat keputusan dalam bentuk tindakan untuk memajukan sains.

Sekolah penelitian, di SDN Tegalrejo 1, SDN Petinggen, SDN Bener dan SDN Bangunrejo 1 meningkatkan kemampuan literasi sains kepada siswa juga melalui praktik langung meskipun kegiatan tersebut tidak dijadwalkan pada kegiatan GLS atau jadwal literasi, melainkan pada kegiatan Jumat Bersih, gotong royong kelas dan sekolah. Melalui kegiatan tersebut diharapkan dapat menumbuhkan kepedulian siswa terhadap lingkungan sekitar, kebersihan, kesehatan dan juga pelestarian ekosistem. Mengingat bahwa sekolah-sekolah penelitian berada dekat dengan kenampakan alam seperti sungai dan sawah. Khususnya di SDN Bangunrejo 1 dan SDN Bener, lokasi yang sangat berdekatan dengan sungai besar dan berdasarkan pengamatan serta wawancara dengan guru dan siswa, penumbuhan kesadaran siswa tentang lingkungan sangatlah diperlukan melalui praktik langsung karna dampaknya apabila siswa tidak memiliki kepedulian terhadap lingkungan sekitar akan langsung berimbas pada sekolah yang sering mengalami banjir dikarenakan luapan air yang disebabkan banyaknya sampah dialiran sungai.

SDN Bener Kecamatan Tegalrejo Yogyakarta dalam meningkatkan kemampuan literasi siswanya memiliki cara khusus yaitu dengan melakukan pengenalan literasi pada siswanya melalui beragam kegiatan. Dalam satu minggu, sekolah ini memiliki jadwal yang berbeda dalam mengenalkan literasi. Ada kegiatan jumat bersih, sarapan bersama, mengaji bersama dan lain sebagainya. Pada saat penelitian berlangsung, siswa kelas V SD bersama siswa lainnya di SDN Bener sedang mengadakan sarapan bersama. Hal tersebut sengaja dilakukan supaya siswa memiliki kesadaran tentang kesehatan tubuh mereka dengan makan makanan sehat dan bergizi, serta meningkatkan literasi sosial siswa dengan berkegiatan bersama dan saling menghormati dengan guru dan siswa dari kelas lainnya.

Merujuk pada pendapat Sudjana dan Ibrahim (2012) menyebutkan bahwa terdapat sumber belajar yang dirancang untuk mendukung kepentingan kegiatan belajar. Seperti halnya dengan kegiatan literasi yang dilakukan di SDN Bener, mereka memadukan 
buku (learning resources by design) dengan teknik praktik langsung (learning resources by utilization) guna menunjang kegiatan literasi sains sehingga siswa tidak hanya berkemampuan dalam pengetahuan saja tetapi juga mampu melakukannya dalam bentuk tindakan.

\section{PENUTUP}

\section{Simpulan}

Berdasarkan hasil penelitian yang diakukan di kecamatan Tegalrejo Yogyakarta ditemukan bahwa sumber belajar berupa buku cerita, multimedia, video pembelajaran dan juga melalui teknik pengenalan literasi sains dengan praktik langsung dapat digunakan sebagai upaya peningkatan literasi sains di kegiatan GLS sekolah dasar. Buku cerita dan teknik praktik langsung menjadi sumber belajar yang paling banyak dan sering digunakan dalam menunjang kegiatan GLS di SD. Hal tersebut dikarenakan kemudahan buku cerita untuk dipersiapkan dan dapat langsung digunakan oleh guru maupun siswa.

Sekolah-sekolah penelitian tersebut menggunakan beragam sumber belajar dalam tiap kegiatan literasinya yang disesuaikan dengan jadwal serta kebutuhan siswa dikarenakan dalam sekolah dasar tidak hanya literasi sains yang perlu ditingkatkan tetapi juga terdapat beragam literasi dasar lainnya. Melalui penggunaan ragam sumber belajar diharapkan siswa termotivasi untuk meningkatkan kemampuan literasinya dan membuat siswa tidak bosan sehingga pelaksanaan GLS dapat berjalan optimal.

\section{Saran}

Penggunaan sumber belajar diperlukan untuk menunjang pelaksanaan GLS. Dalam penelitian yang dilakukan ini membahas tentang macam-macam sumber belajar yang dapat digunakan untuk meningkatkan literasi sains di sekolah dasar kecamatan Tegalrejo Yogyakarta sehingga masih diperlukan data sahih yang menjelaskan terkait keefektifan sumber belajar dalam peningkatan literasi sains di sekolah dasar. Hal tersebut bertujuan untuk mengetahui manakah dari macam sumber belajar yang efektif digunakan dalam kegiatan GLS sehingga kemampuan literasi sains siswa dapat dinyatakan meningkat dan menjelaskan tentang keterlaksanaan GLS di sekolah dasar yang baik.

Dalam kegiatan GLS terdapat tiga tahapan yaitu pembiasaan, pengembangan dan pembelajaran. Pada penelitian ini fokus pembahasan masih di tahapan pembiasan, belum memperhatikan sumber belajar yang digunakan oleh sekolah dasar pada tahapan pengembangan maupun pembelajaran di GLS sehingga belum diketahui jenis sumber belajar lain yang mungkin dapat digunakan pada tahapan tersebut.

\section{DAFTAR PUSTAKA}

de SOUSA, L., RICHTER, B., \& NEL, C. (2017). The effect of multimedia use on the teaching and learning of Social Sciences at tertiary level: a case study. Yesterday and Today, 17, 1-22. https://doi.org/10.17159/22230386/2017/n17a1

Fananta, M. R., dkk. (2017). Materi Pendukung Literasi Sains (L. A. Mayani, Ed.). Kementerian Pendidikan dan Kebudayaan.

Idami, Z. (2018). Students' Perception On The Used Of Liquid Crystal Display (Lcd) Projector In English Foreign Language (Efl) Classroom. JL3T Journal of Linguistics, Literature \& Language Teaching JL3T: Vol. IV (Issue 2).

Joshi, R. M., Alves, R., Goswami, U., Chang, C. M., Oakhill, J., \& Treiman, R. (n.d.). Literacy Studies. http://www.springer.com/series/7206

Lindsay, S. (2011). Scientific Literacy: A Symbol for Change. Scientific Literacy Under the Microscope: A Whole School Approach, 11, 3-15. 
Miles, M. B., Huberman, A. M., \& Saldana, J. (2014). Qualitative Data Analysis: A Methods Sourcebook (3rd Edition). Sage Publications.

Sudjana, N., \& Ibrahim. (2012). Penelitian dan Penilaian Pendidikan. Sinar Baru Algensindo.

Tompkins, G. E. (2017). Literacy for the 21st Century: A Balanced Approach. www.pearsoned.com/permissions/.

Wiedari, P. dkk. (2016). Desain Induk Gerakan Literasi Sekolah. Kementerian Pendidikan dan Kebudayaan. 